\title{
PERANCANGAN APLIKASI E-COMMERCE BERBASIS ANDROID PADA UD HOKY CELLULER SHOP
}

\author{
Adam Surya Wijaya ${ }^{1)}$, Johanes Fernandes Andry ${ }^{2)}$ \\ ${ }^{1,2}$ Sistem Informasi, Universitas Bunda Mulia \\ ${ }^{1,2} \mathrm{Jl}$. Lodan Raya No.2, Jakarta Utara \\ Email:1adam@suryawijayateknik.com,2jf_andry@kreavindo.com
}

\begin{abstract}
Technology helps people to sell their product by using smartphone and internet. People no longer need to come to the store to buy their desired product and very helpful for people who cannot go directly to the store because of the distance and the location of the store. Internet helps business to sell their products in website or application so people can comfortably buy their desired products wherever and whenever also business can get a new customer. Hoky Celluler Shop sells smartphones and its accessories like powerbank, USB cable, etc. Hoky Celluler Shop wants to expand its business by using e-commerce in smartphone so it can gain a new customer and make its customer satisfied because, by using ecommerce in smartphone people can buy their desired product from their home and people who don't know about Hoky Cellular Shop can become Hoky Celluler Shop's new customers if they are satisfied with the services provided to them. Android based e-commerce is designed using SDLC (Systems Development Life Cycle) Waterfall method. This application is expected to help Hoky Celluler Shop gain new customers and have a report for its sales and products also make its customer satisfied with faster and convenient service.
\end{abstract}

Keyword: Information System, Android, E-commerce

\begin{abstract}
Abstrak
Teknologi membantu orang - orang untuk menjual produknya dengan menggunakan smartphone and internet. Orang orang tidak perlu datang ke toko untuk membeli produk yang diinginkan dan sangat membantu untuk orang - orang yang tidak dapat datang ke toko langsung karena jarak dan lokasi toko. Internet membantu bisnis untuk menjual produknya di website ataupun melalui aplikasi sehingga orang - orang dapat dengan nyaman membeli produk yang diinginkan dimanapun dan kapanpun serta bisnis dapat mendapatkan pelanggan baru. Hoky Celluler Shop menjual smartphone dan aksesorisnya seperti powerbank, kabel USB, dan lain - lain. Hoky Celluler Shop ingin memperluas bisnisnya dengan menggunakan e-commerce di smartphone sehingga Hoky Celluler Shop bisa mendapatkan pelanggan baru dan memuaskan pelanggannya karena dengan menggunakan e-commerce di smartphone orang - orang dapat membeli produk yang diinginkan dari rumah mereka dan orang - orang yang belum mengetahui tentang Hoky Celluler Shop dapat menjadi pelanggan baru dari Hoky Celluler Shop apabila mereka puas dengan layanan yang diberikan kepada mereka. E-commerce berbasis android dibuat dengan menggunakan metode SDLC (System Development Life Cycle) waterfall. Aplikasi ini diharapkan dapat membantu Hoky Celluler Shop mendapatkan pelanggan baru dan mempunyai laporan untuk penjualan dan juga produk - produknya serta membuat pelanggannya puas dengan layanan yang lebih cepat dan mudah.
\end{abstract}

Kata Kunci: Android, E-commerce, SDLC Waterfall

\section{Pendahuluan}

Penggunaan teknologi sangat memberikan manfaat yang besar terhadap dunia bisnis. Perusahaan yang menggunakan teknologi merupakan perusahaan yang mampu bersaing dalam kompetisi. Salah satu teknologi yang dapat meningkatkan persaingan bisnis adalah penggunaan electronic commerce (e-commerce), dimana e-commerce digunakan untuk memasarkan berbagai macam produk maupun jasa baik dalam bentuk fisik maupun digital [1].

Saat ini strategi yang baik sangat diperlukan dalam memasarkan produk. E-commerce sangat tepat digunakan dalam memasarkan produk - produk yang dijual oleh suatu toko [2]. E-commerce dapat memudahkan transaksi antara penjual dan pembeli yang berbeda tempat serta pembeli dapat mengetahui info produk seperti harga, model, warna, dan info produk lainnya dengan mudah [3].

Perkembangan e-commerce sangat cepat meningkat di Indonesia, hal tersebut mengharuskan semua pelaku usaha untuk dapat beradaptasi dengan menjual produknya secara online. Teknologi yang semakin maju dapat mempermudah proses bisnis suatu usaha [4].

Penggunaan smartphone yang meningkat di seluruh dunia membuat pengembangan e-commerce bergeser dari website menjadi smartphone [5]. Saat ini smartphone 
membantu segala macam kegiatan manusia seperti mengirim dan menerima pesan, memesan kebutuhan hidup seperti makanan dan minuman ataupun kebutuhan sekunder lainnya [6].

Smartphone android saat ini hampir dimiliki oleh seluruh lapisan masyarakat dan digunakan untuk hiburan, komunikasi, berbisnis, jual beli barang melalui aplikasi dan sebagainya [7].

UD Hoky Celluler Shop adalah usaha dagang yang menjual handphone dan aksesorisnya. UD Hoky Celluler Shop ingin memperluas bisnis dengan menjual produknya melalui android karena dengan menjual produknya melalui android, UD Hoky Celuller Shop dapat meningkatkan kepuasan pelanggannya serta mendapatkan pelanggan baru.

Untuk memenuhi kebutuhan tersebut dibuatlah perancangan aplikasi e-commerce berbasis android untuk membantu UD Hoky Celluler Shop meningkatkan kepuasan pelanggan serta mendapatkan pelanggan baru dan juga mempermudah proses bisnisnya karena UD Hoky Celluler Shop tidak mempunyai pencatatan terkait stok barang yang dimiliki dan penyimpanan barang diatur oleh owner, sehingga apabila pelanggan ingin membeli suatu barang, pelanggan harus menunggu karena owner perlu mengecek terlebih dahulu apakah barang tersebut ada atau tidak. Pencatatan laporan penjualan yang menggunakan kertas atau secara manual juga menimbulkan risiko terjadinya kehilangan catatan laporan dan juga kertas tersebut dapat rusak.

\section{Tinjauan Pustaka}

\subsection{E-commerce}

E-commerce merupakan cara untuk menjual suatu produk secara online dengan memanfaatkan internet. Internet merupakan suatu jaringan komputer yang saling terhubung dan digunakan untuk keperluan informasi dan komunikasi. Internet juga dapat diartikan sebagai jaringan komputer di seluruh dunia yang digunakan sebagai komunikasi data berupa gambar, suara, video, teks, dan sebagainya [8]. E-commerce membantu dalam mempromosikan produk karena dengan e-commerce, modal untuk mempromosikan suatu produk tidak diperlukan dan sangat menghemat waktu. E-commerce dapat menjual barang ataupun jasa sehingga semua orang dapat mengembangkan bisnis dan bersaing dengan kompetitor lainnya dan e-commerce dapat menurunkan biaya operasional [9].

\subsection{Android}

Android adalah sistem operasi yang menyediakan platform terbuka untuk membuat aplikasi smartphone sesuai dengan keinginan para pengembang dimana sistem operasi ini berbasis linux. Android awalnya dikembangkan oleh Android Inc, sebuah perusahaan yang membuat software untuk handphone yang kemudian dibeli oleh Google Inc. Terdapat 34 perusahaan hardware, software, dan telekomunikasi termasuk Google, HTC, Intel, dan lainnya yang tergabung dalam Open Handset Alliance (OHA) yang dibentuk untuk pengembangan android [10].

Database merupakan kumpulan data yang saling berkaitan dan diorganisasikan berdasarkan skema atau struktur tertentu. Data - data tersebut disimpan di dalam komputer dan dapat diolah menjadi informasi menggunakan software [11]. Database yang digunakan Android adalah SQLite. SQLite adalah library yang menerapkan database dimana SQLite tidak membutuhkan banyak dukungan dari library eksternal atau dari sistem informasi dan SQLite dapat mengakses database secara langsung baik read maupun write. Database SQLite dapat dikendalikan dari jarak jauh dengan menggunakan jaringan komputer baik secara lokal maupun internet [12].

\subsection{SDLC Waterfall}

SDLC (Systems Development Life Cycle) Waterfall adalah proses pengembangan software yang berurutan dimana prosesnya mengalir ke bawah seperti air terjun. Tahapan pada SDLC Waterfall harus diselesaikan secara berurutan satu demi satu dan tidak dapat pindah ke tahapan selanjutnya apabila tahapan sebelumnya belum selesai sepenuhnya [13].

\section{Metode Penelitian}

Metode yang digunakan untuk mengumpulkan data adalah metode kualitatif yaitu metode yang mengumpulkan data melalui bahasa tutur, bahasa tubuh, perilaku maupun ungkapan - ungkapan lainnya [14]. Salah satu cara yang sering digunakan dalam penelitian kualitatif adalah wawancara. Wawancara dilakukan untuk mendapatkan informasi dengan memberikan beberapa pertanyaan informal [15].

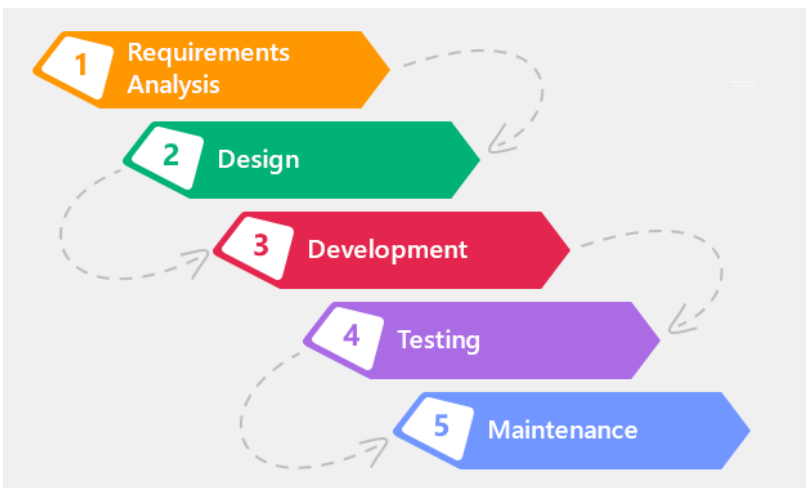

Gambar 1. SDLC Waterfall [13]

Metode perancangan aplikasi e-commerce berbasis android ini menggunakan metode SDLC Waterfall yang dapat dilihat pada Gambar 1. Berikut adalah penjelasan tahapan SDLC Waterfall yang digunakan dalam perancangan aplikasi e-commerce berbasis android pada UD Hoky Celluler Shop:

A. Requirements Analysis

Tahap pertama adalah melakukan analisis masalah apa saja yang dialami pada UD Hoky Celluler Shop, kemudian menganalisis kebutuhan apa saja yang dibutuhkan aplikasi untuk mengatasi masalah tersebut. Untuk mengetahui masalah apa saja yang dialami dan 
kebutuhan apa saja yang dibutuhkan oleh UD Hoky Celluler Shop maka akan dilakukan wawancara dengan pemilik serta karyawan UD Hoky Celluler Shop

\section{B. Design}

Tahap selanjutnya adalah melakukan desain tampilan aplikasi yang akan dibuat. Desain dibuat berdasarkan kebutuhan yang sudah dianalisis sebelumnya pada tahap requirement analysis

\section{Development}

Pada tahap ini, aplikasi akan dibuat berdasarkan desain yang sudah dirancang sebelumnya pada tahap design. Rancangan tersebut digunakan untuk mempermudah pembuatan aplikasi dan juga aplikasi yang dibuat sesuai dengan kebutuhan dan dapat mengatasi masalah yang dimiliki oleh UD Hoky Celluler Shop.

\section{Testing}

Pada tahap ini, aplikasi yang sudah dibuat akan diuji terlebih dahulu untuk mengetahui apakah aplikasi berjalan dengan baik dan apakah semua fungsi yang ada pada aplikasi berjalan sesuai dengan fungsinya. Tahap ini juga dilakukan untuk mencari apakah ada bug dan error yang terdapat pada aplikasi sehingga pada saat aplikasi diimplementasi bug dan error tersebut dapat dihindari.

\section{E. Maintenance}

Tahap ini dilakukan setelah aplikasi diimplementasi dimana tahap ini dilakukan untuk menjaga aplikasi agar tetap berjalan dengan baik dan juga memperbaiki bug dan error yang tidak ditemukan pada saat tahap testing.

\section{Hasil dan Pembahasan}

\subsection{Requirement Analysis}

Berikut adalah masalah dan kebutuhan yang diperlukan UD Hoky Celluler Shop berdasarkan wawancara yang dilakukan dengan pemiliki serta karyawan UD Hoky Celluler Shop:

1. Identifikasi Masalah

- UD Hoky Celluler Shop ingin memperluas bisnisnya

- UD Hoky Celluler Shop ingin meningkatkan kepuasan pelanggan dan juga mendapatkan pelanggan baru

- UD Hoky Celluler Shop tidak mempunyai pencatatan terkait stok barang yang dimiliki

- Pencatatan laporan penjualan yang dilakukan secara manual memiliki risiko untuk terjadinya kehilangan catatan laporan

2. Identifikasi Kebutuhan Aplikasi

- Internal / UD Hoky Celluler Shop

- Melakukan input data barang ke dalam aplikasi

- Melakukan pengubahan dan penghapusan data barang

- Memproses pesanan online dari pelanggan

- Melihat laporan penjualan

- Melihat stok barang

- Melakukan input transaksi yang terjadi secara offline ke dalam aplikasi
- Eksternal / Pelanggan

- Melihat list produk yang dijual oleh UD Hoky Celluler Shop

- Melakukan pemesanan melalui aplikasi

- Melakukan input data diri

- Mengubah data diri

\subsection{Design}

Berdasarkan analisis yang sudah dilakukan maka rancangan database relasional yang dibuat untuk memenuhi kebutuhan aplikasi dapat dilihat pada Gambar 2.

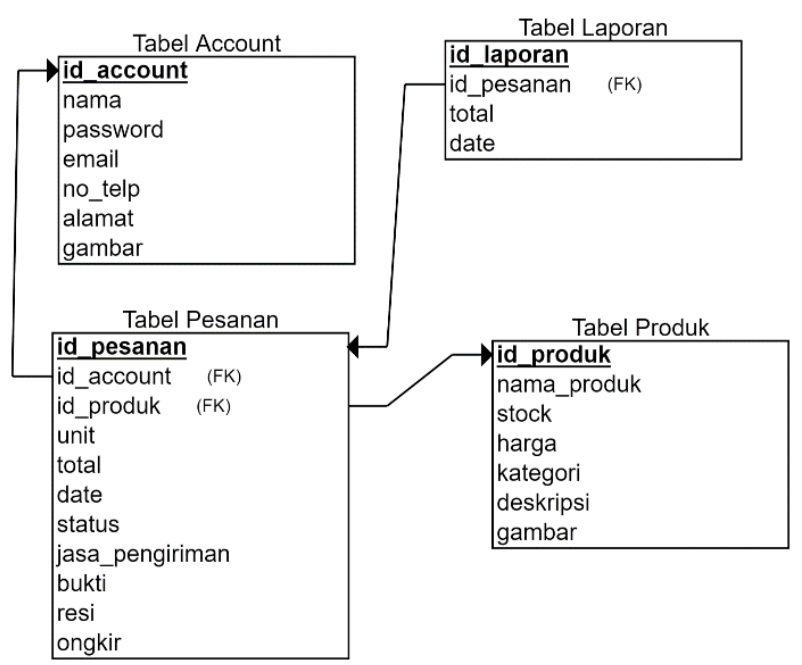

Gambar 2. Database Relasional

Terdapat 4 tabel dalam database relasional yang dapat dilihat pada Gambar 2. Tabel pertama merupakan tabel account yang berisi data - data pengguna seperti id_account, nama pengguna, password, email, nomor telepon, alamat, dan juga foto pengguna yang digunakan untuk login ke dalam aplikasi.

Tabel kedua merupakan tabel produk yang berisi data - data produk seperti id_produk, nama_produk, stok produk, harga produk, kategori produk, deskripsi produk, dan gambar produk.

Tabel ketiga merupakan tabel pesanan yang berisi data - data pesanan seperti id_pesanan, id_account, id_produk, jumlah produk (unit), total pembayaran, tanggal pesanan, status pesanan, jasa_pengiriman, bukti pembayaran, resi pengiriman, dan ongkos kirim. Id_account, dan id_produk merupakan foreign key dari tabel account dan produk.

Tabel keempat merupakan tabel laporan yang berisi data - data laporan penjualan seperti id_laporan, $i d$ pesanan, total pembayaran, dan tanggal laporan tersebut dibuat. Id_pesanan merupakan foreign key dari tabel pesanan. Tabel - tabel tersebut menyimpan semua data yang dibutuhkan oleh aplikasi agar aplikasi dapat menampilkan informasi sesuai dengan kebutuhan.

Berikut adalah gambaran fungsi apa saja yang dapat dilakukan oleh pengguna dalam aplikasi yang digambarkan dengan menggunakan Use Case Diagram 
pada Gambar 3.

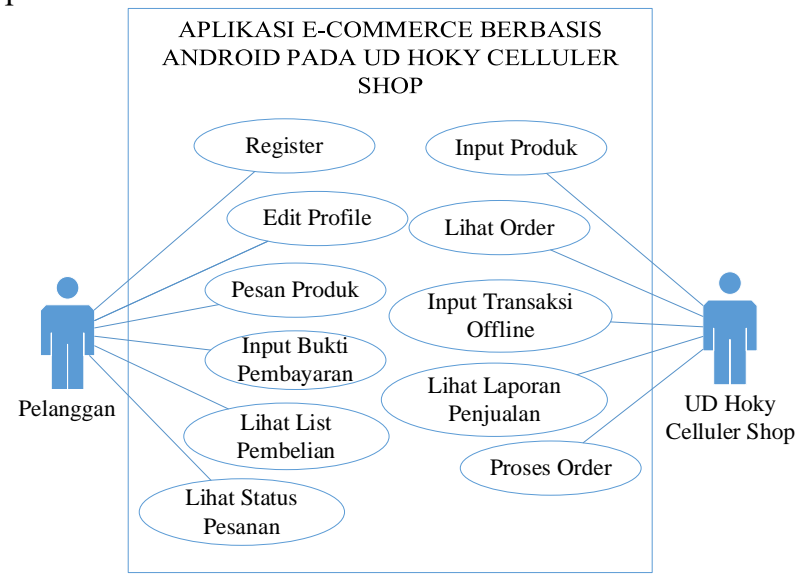

Gambar 3. Use Case Diagram

Terdapat 2 pengguna pada use case diagram yang dapat dilihat pada Gambar 3. Pengguna pertama yaitu pelanggan dapat melakukan registrasi, login aplikasi, mengubah data diri, memesan produk yang diinginkan, melakukan input bukti pembayaran, melihat list pembelian yang sudah dilakukan, dan melihat status pesanan. Pengguna kedua yaitu UD Hoky Celluler Shop dapat melakukan login aplikasi, melakukan input data produk, melihat pesanan pelanggan, melakukan input transaksi yang terjadi di tempat (offline), melihat laporan penjualan, dan memproses pesanan online.

\subsection{Development}

Setelah rancangan dibuat maka, rancangan database relasional dan juga use case diagram akan digunakan untuk memudahkan dalam membuat aplikasi. Aplikasi akan dibuat menggunakan Android Studio dengan bahasa pemrograman Java. Database yang digunakan adalah database SQLite. Berikut adalah modul dari aplikasi android e-commerce UD Hoky Celluler Shop.

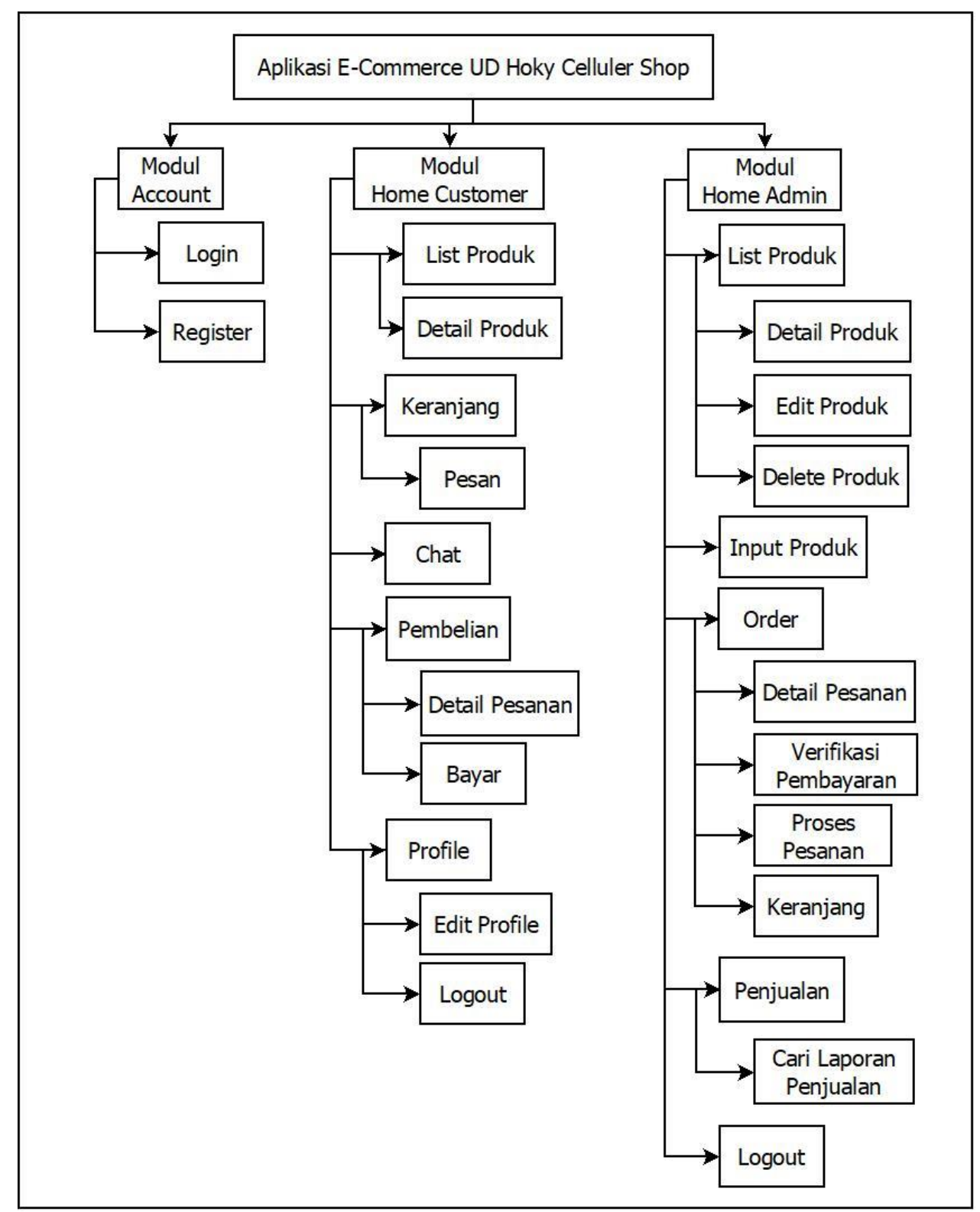

Gambar 4. Modul Aplikasi E-Commerce UD Hoky Celluler Shop 
Gambar 4 merupakan gambar modul aplikasi $e$ commerce UD Hoky Celluler Shop. Terdapat 3 modul utama dalam aplikasi tersebut yaitu modul Account, modul Home Admin, dan modul Home Customer. Modul Account berisi Login dan Register dimana Login berfungsi untuk masuk ke dalam aplikasi sedangkan register berfungsi untuk membuat akun untuk masuk ke dalam aplikasi. Modul Home Customer berisi List Produk, Keranjang, Chat, Pembelian, dan Profile. List Produk berfungsi untuk melihat daftar produk yang tersedia dan juga terdapat fungsi Detail Produk untuk melihat deskripsi produk secara detail dan juga memasukkan produk ke dalam keranjang. Keranjang berfungsi untuk melihat produk yang ada di keranjang belanja dan juga mengubah jumlah produk yang ingin dibeli atau menghapus produk yang tidak ingin dibeli dalam keranjang. Terdapat juga Pesan dalam Keranjang yang berfungsi untuk memesan produk yang ingin dibeli dalam keranjang belanja.

Chat berfungsi untuk berkomunikasi dengan UD Hoky Celluler Shop. Pembelian berfungsi untuk melihat produk yang pernah dipesan dalam aplikasi ataupun produk yang sedang diproses dan dalam pengiriman. Dalam Pembelian terdapat Detail Pesanan yang berfungsi untuk melihat detail pesanan secara lengkap dan juga Bayar yang berfungsi untuk membayar pesanan. Profile berfungsi untuk melihat data diri pengguna seperti nama, email, password, alamat, dan sebagainya. Pada Profile terdapat Edit Profile yang berfungsi untuk mengubah data diri dan juga Logout yang berfungsi untuk keluar dari aplikasi.

Modul Home Admin berisi List Produk, Input Produk, Order, Penjualan, dan Logout. List Produk berfungsi untuk melihat daftar produk yang dapat dibeli oleh pelanggan maupun produk yang sudah habis dipesan oleh pelanggan. Pada List Produk terdapat Detail Produk, Edit Produk, dan Delete Produk. Detail Produk berfungsi untuk melihat deskripsi produk secara detail dan juga memasukkan produk ke dalam keranjang apabila ada pelanggan yang data ke tempat untuk membeli produk yang diinginkan pelanggan tersebut. Edit Produk berfungsi untuk mengubah data produk seperti nama, stok, gambar, dan sebagainya. Delete Produk berfungsi untuk menghapus produk. Input Produk berfungsi untuk memasukkan produk baru ke dalam aplikasi. Order berfungsi untuk melihat dan memproses pesanan dari pelanggan. Pada Order terdapat Detail Pesanan, Verifikasi Pembayaran, Proses Pesanan, dan Input Transaksi Offline. Detail Pesanan berfungsi untuk melihat detail pesanan secara lengkap, Verifikasi Pembayaran berfungsi untuk melihat apakah pelanggan sudah melakukan pembayaran atau belum, Proses Pesanan berfungsi untuk memproses pesanan pelanggan yang sudah diverifikasi dan Keranjang berfungsi untuk melihat produk yang dipesan oleh pelanggan yang datang ke tempat dan juga untuk menginput pesanan tersebut ke dalam laporan. Penjualan berfungsi untuk melihat laporan penjualan baik laporan penjualan yang terjadi secara online maupun offline. Pada laporan terdapat Cari Laporan Penjualan yang berfungsi untuk mencari laporan penjualan berdasarkan tanggal.
Logout berfungsi untuk keluar dari aplikasi.

\subsection{Testing}

Pada tahap ini, aplikasi yang sudah dibuat akan diuji menggunakan User Acceptance Testing (UAT) terlebih dahulu untuk mengetahui apakah semua fungsi yang ada pada aplikasi berjalan sesuai dengan fungsinya dan juga mencari bug dan error yang terdapat pada aplikasi. Modul Home Customer dan Home Admin akan diuji menggunakan User Acceptance Testing (UAT). Berikut adalah tabel hasil dari User Acceptance Testing (UAT).

Tabel 1. Testing Tampilan Home Customer

\begin{tabular}{|c|c|c|c|}
\hline Test Case & Text Step & $\begin{array}{c}\text { Expected } \\
\text { Result }\end{array}$ & $\begin{array}{l}\text { Actual } \\
\text { Result }\end{array}$ \\
\hline $\begin{array}{l}\text { 1. Membuka } \\
\text { halaman } \\
\text { Profile }\end{array}$ & $\begin{array}{l}\text { 1. Buka } \\
\text { aplikasi } \\
\text { 2. Login akun } \\
\text { customer } \\
\text { dengan benar } \\
\text { 3. Tekan } \\
\text { tombol Profile }\end{array}$ & $\begin{array}{l}\text { Aplikasi } \\
\text { menampi } \\
\text { lkan } \\
\text { halaman } \\
\text { Profile }\end{array}$ & $\begin{array}{c}\text { Aplikasi } \\
\text { berhasil } \\
\text { menampi } \\
\text { lkan } \\
\text { halaman } \\
\text { Profile }\end{array}$ \\
\hline $\begin{array}{l}\text { 2. Membuka } \\
\text { halaman } \\
\text { Detail } \\
\text { Produk }\end{array}$ & $\begin{array}{l}\text { 1. Buka } \\
\text { aplikasi } \\
\text { 2. Login akun } \\
\text { customer } \\
\text { dengan benar } \\
\text { 3. Tekan } \\
\text { gambar } \\
\text { produk }\end{array}$ & $\begin{array}{c}\text { Aplikasi } \\
\text { menampi } \\
\text { lkan } \\
\text { halaman } \\
\text { Detail } \\
\text { Produk }\end{array}$ & $\begin{array}{c}\text { Aplikasi } \\
\text { berhasil } \\
\text { menampi } \\
\text { lkan } \\
\text { halaman } \\
\text { Detail } \\
\text { Produk }\end{array}$ \\
\hline $\begin{array}{l}\text { 3. Membuka } \\
\text { halaman } \\
\text { Keranjang }\end{array}$ & $\begin{array}{l}\text { 1. Buka } \\
\text { aplikasi } \\
\text { 2. Login akun } \\
\text { customer } \\
\text { dengan benar } \\
\text { 3. Tekan } \\
\text { tombol } \\
\text { Keranjang }\end{array}$ & $\begin{array}{c}\text { Aplikasi } \\
\text { menampi } \\
\text { lkan } \\
\text { halaman } \\
\text { Keranjan } \\
\text { g }\end{array}$ & $\begin{array}{c}\text { Aplikasi } \\
\text { berhasil } \\
\text { menampi } \\
\text { lkan } \\
\text { halaman } \\
\text { Keranjan } \\
\text { g }\end{array}$ \\
\hline $\begin{array}{l}\text { 4. Membuka } \\
\text { halaman } \\
\text { Pembelian }\end{array}$ & $\begin{array}{l}\text { 1. Buka } \\
\text { aplikasi } \\
\text { 2. Login akun } \\
\text { customer } \\
\text { dengan benar } \\
\text { 3. Tekan } \\
\text { tombol } \\
\text { Pembelian }\end{array}$ & $\begin{array}{c}\text { Aplikasi } \\
\text { menampi } \\
\text { lkan } \\
\text { halaman } \\
\text { Pembelia } \\
\text { n }\end{array}$ & $\begin{array}{c}\text { Aplikasi } \\
\text { berhasil } \\
\text { menampi } \\
\text { lkan } \\
\text { halaman } \\
\text { Pembelia } \\
\text { n }\end{array}$ \\
\hline $\begin{array}{l}\text { 5. Membuka } \\
\text { halaman List } \\
\text { Produk }\end{array}$ & $\begin{array}{l}\text { 1. Buka } \\
\text { aplikasi } \\
\text { 2. Login akun } \\
\text { customer } \\
\text { dengan benar } \\
\text { 3. Tekan } \\
\text { tombol } \\
\text { Pembelian }\end{array}$ & $\begin{array}{c}\text { Aplikasi } \\
\text { menampi } \\
\text { lkan } \\
\text { halaman } \\
\text { List } \\
\text { Produk }\end{array}$ & $\begin{array}{c}\text { Aplikasi } \\
\text { berhasil } \\
\text { menampi } \\
\text { lkan } \\
\text { halaman } \\
\text { List } \\
\text { Produk }\end{array}$ \\
\hline
\end{tabular}

Tabel 1 merupakan tabel yang berisi pengujian terhadap tampilan Home Customer yang dilakukan untuk mengetahui apakah fungsi pada Home Customer berjalan dengan baik sesuai rancangan yang dibuat. Berdasarkan hasil User Acceptance Testing (UAT) yang dapat dilihat 
pada Tabel 1, fungsi pada Home Customer sudah berjalan dengan baik sesuai dengan apa yang seharusnya dilakukan. Tidak ditemukan bug maupun error dalam tampilan Home Customer tersebut.

Tabel 2. Testing Tampilan Home Admin

\begin{tabular}{|c|c|c|c|}
\hline Test Case & Text Step & $\begin{array}{c}\text { Expected } \\
\text { Result }\end{array}$ & $\begin{array}{l}\text { Actual } \\
\text { Result }\end{array}$ \\
\hline $\begin{array}{l}\text { 1. Membuka } \\
\text { halaman } \\
\text { Input Produk }\end{array}$ & $\begin{array}{l}\text { 1. Buka } \\
\text { aplikasi } \\
\text { 2. Login akun } \\
\text { admin dengan } \\
\text { benar } \\
\text { 3. Tekan } \\
\text { tombol Input } \\
\text { Produk }\end{array}$ & $\begin{array}{c}\text { Aplikasi } \\
\text { menampi } \\
\text { lkan } \\
\text { halaman } \\
\text { Input } \\
\text { Produk }\end{array}$ & $\begin{array}{c}\text { Aplikasi } \\
\text { berhasil } \\
\text { menampi } \\
\text { lkan } \\
\text { halaman } \\
\text { Input } \\
\text { Produk }\end{array}$ \\
\hline $\begin{array}{l}\text { 2. Membuka } \\
\text { halaman } \\
\text { Order }\end{array}$ & $\begin{array}{l}\text { 1. Buka } \\
\text { aplikasi } \\
\text { 2. Login akun } \\
\text { admin dengan } \\
\text { benar } \\
\text { 3. Tekan } \\
\text { tombol Order }\end{array}$ & $\begin{array}{c}\text { Aplikasi } \\
\text { menampi } \\
\text { lkan } \\
\text { halaman } \\
\text { Order }\end{array}$ & $\begin{array}{c}\text { Aplikasi } \\
\text { berhasil } \\
\text { menampi } \\
\text { lkan } \\
\text { halaman } \\
\text { Order }\end{array}$ \\
\hline $\begin{array}{l}\text { 3. Membuka } \\
\text { halaman } \\
\text { Penjualan }\end{array}$ & $\begin{array}{l}\text { 1. Buka } \\
\text { aplikasi } \\
\text { 2. Login akun } \\
\text { admin dengan } \\
\text { benar } \\
\text { 3. Tekan } \\
\text { tombol } \\
\text { Penjualan }\end{array}$ & $\begin{array}{c}\text { Aplikasi } \\
\text { menampi } \\
\text { lkan } \\
\text { halaman } \\
\text { Penjuala } \\
\text { n }\end{array}$ & $\begin{array}{c}\text { Aplikasi } \\
\text { berhasil } \\
\text { menampi } \\
\text { lkan } \\
\text { halaman } \\
\text { Penjuala } \\
\text { n }\end{array}$ \\
\hline $\begin{array}{l}\text { 4. Keluar } \\
\text { dari aplikasi }\end{array}$ & $\begin{array}{l}\text { 1. Buka } \\
\text { aplikasi } \\
\text { 2. Login akun } \\
\text { admin dengan } \\
\text { benar } \\
\text { 3. Tekan } \\
\text { tombol Logout }\end{array}$ & $\begin{array}{c}\text { Aplikasi } \\
\text { menampi } \\
\text { lkan } \\
\text { halaman } \\
\text { Login }\end{array}$ & $\begin{array}{c}\text { Aplikasi } \\
\text { berhasil } \\
\text { menampi } \\
\text { lkan } \\
\text { halaman } \\
\text { Login }\end{array}$ \\
\hline $\begin{array}{l}\text { 5. Membuka } \\
\text { halaman List } \\
\text { Produk }\end{array}$ & $\begin{array}{l}\text { 1. Buka } \\
\text { aplikasi } \\
\text { 2. Login akun } \\
\text { admin dengan } \\
\text { benar } \\
\text { 3. Tekan } \\
\text { tombol List } \\
\text { Produk }\end{array}$ & $\begin{array}{c}\text { Aplikasi } \\
\text { menampi } \\
\text { lkan } \\
\text { halaman } \\
\text { List } \\
\text { Produk }\end{array}$ & $\begin{array}{c}\text { Aplikasi } \\
\text { berhasil } \\
\text { menampi } \\
\text { lkan } \\
\text { halaman } \\
\text { List } \\
\text { Produk }\end{array}$ \\
\hline
\end{tabular}

Tabel 2 merupakan tabel yang berisi pengujian terhadap tampilan Home Admin yang dilakukan untuk mengetahui apakah fungsi pada Home Admin berjalan dengan baik sesuai rancangan yang dibuat. Berdasarkan hasil User Acceptance Testing (UAT) yang dapat dilihat pada Tabel 2, fungsi pada Home Admin sudah berjalan dengan baik sesuai dengan apa yang seharusnya dilakukan. Tidak ditemukan bug maupun error dalam tampilan Home Admin tersebut.

\subsection{Maintenance}

Tahap ini dilakukan setelah aplikasi diimplementasi dimana tahap ini dilakukan untuk menjaga aplikasi agar tetap berjalan dengan baik dan juga memperbaiki bug dan error yang tidak terdeteksi pada saat tahap testing. Maintenance yang dilakukan adalah pemeliharaan server database dan juga aplikasi. Maintenance server dilakukan untuk memastikan bahwa data yang ada pada database tersimpan dengan baik tanpa adanya data yang error atau tidak lengkap dan server yang digunakan tidak overheat maupun lambat dalam memproses data. Maintenance yang dilakukan pada aplikasi bertujuan untuk memastikan bahwa setelah implementasi dan digunakan oleh banyak pengguna, aplikasi tetap berjalan dengan baik.

\subsection{Tampilan Aplikasi}

Berikut merupakan tampilan aplikasi yang sudah dibuat berdasarkan rancangan yang sudah dibuat pada tahap design.

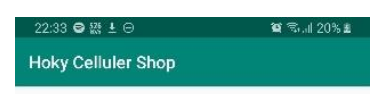

\section{Hoky Celluler Shop}

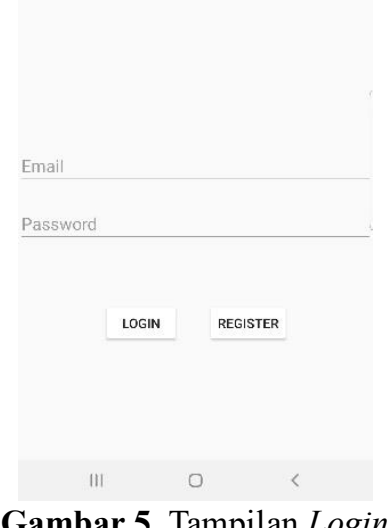

Gambar 5. Tampilan Login

Tampilan login pada Gambar 5 merupakan tampilan awal pada saat aplikasi dibuka. Pengguna perlu mengisi email dan password yang sudah didaftarkan sebelumnya pada aplikasi. Setelah pengguna mengisi email dan password tekan tombol login untuk masuk ke dalam aplikasi. Aplikasi akan membaca email dan password yang dimasukkan oleh pengguna kemudian akan menampilkan tampilan home dari aplikasi. Apabila email yang dimasukkan merupakan email UD Hoky Celluler Shop maka aplikasi akan menampilkan tampilan home admin sedangkan apabila email yang dimasukkan bukan email UD Hoky Celluler Shop maka aplikasi akan menampilkan home customer. Pada tampilan login pengguna juga dapat mendaftar dengan menekan tombol register apabila belum mempunyai akun. Pada tampilan register pengguna perlu memasukkan nama lengkap, email, nomor handphone, alamat lengkap, dan password. Aplikasi akan meminta konfirmasi password untuk memastikan bahwa pengguna sudah memasukkan password yang diinginkan dengan benar. Setelah semua data diisi maka pengguna dapat menekan tombol register untuk mendaftar. Pengguna juga dapat kembali ke tampilan login dengan cara menekan tombol login apabila 
pengguna sudah memiliki akun untuk masuk ke dalam aplikasi.

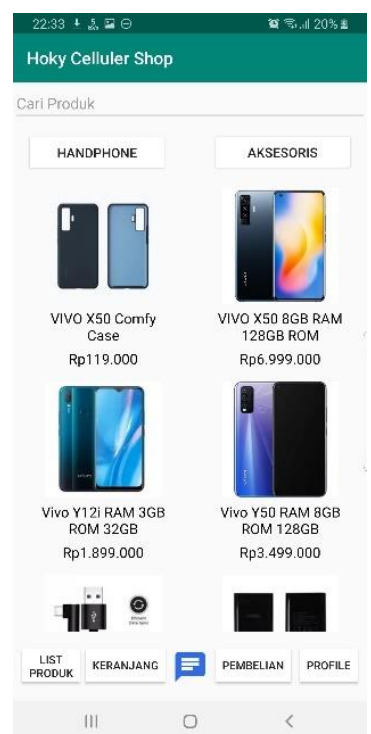

Gambar 6. Tampilan Home Customer

Tampilan home customer pada Gambar 6 merupakan tampilan pada saat pengguna berhasil login ke dalam aplikasi. Pengguna dapat melihat produk yang tersedia pada UD Hoky Celluler Shop. Pengguna juga dapat mencari produk dengan memasukkan nama produk kemudian aplikasi akan menampilkan produk yang dicari apabila tersedia. Pengguna dapat memilih untuk menampilkan semua produk atau menampilkan handphone saja dengan menekan tombol handphone maupun menampilkan aksesoris saja dengan menekan tombol aksesoris. Apabila pengguna ingin membeli produk yang diinginkan maka pengguna dapat menekan gambar produk kemudian aplikasi akan menampilkan detail produk dan pengguna dapat memasukkan produk ke dalam keranjang jika ingin membelinya. Pada tampilan home customer pengguna juga dapat melihat keranjang belanja dengan menekan tombol keranjang kemudian aplikasi akan menampilkan tampilan keranjang yang berisi produk yang sudah dimasukkan keranjang oleh pengguna dan juga total harga produk yang ada pada keranjang. Pengguna dapat menambah jumlah produk yang ingin dibeli, mengurangi jumlah produk yang ingin dibeli, dan menghapus produk yang ingin dibeli apabila pengguna tidak jadi membeli produk tersebut. Apabila pengguna mempunyai pertanyaan, pengguna dapat menekan icon chat kemudian aplikasi akan membuka whatsapp serta nomor dari UD Hoky Celluler Shop langsung terbuka sehingga pengguna dapat langsung menanyakan pertanyaannya. Pengguna perlu memiliki aplikasi whatsapp terlebih dahulu untuk dapat menggunakan fitur tersebut. Pengguna dapat melihat produk yang dipesan dan juga status pesanan dengan menekan tombol pembelian. Data diri pengguna dapat diubah dengan menekan tombol profile kemudian aplikasi akan menampilkan tampilan profile dimana pengguna dapat mengubah data diri dengan menekan tombol edit pada tampilan profile ataupun keluar dari aplikasi dengan menekan tombol logout.

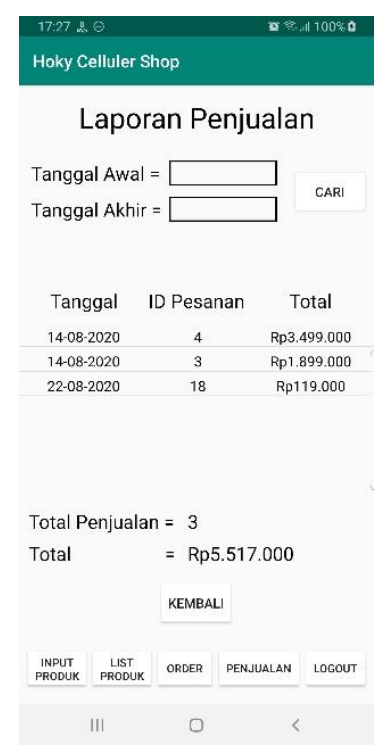

Gambar 7. Tampilan Laporan Penjualan

Dapat dilihat pada Gambar 7, laporan penjualan berisi tanggal laporan dibuat, $i d$ _pesanan yang dicatat ke dalam laporan dan total penghasilan yang didapatkan pada pesanan tersebut. Aplikasi akan menampilkan ada berapa banyak penjualan yang terjadi beserta seluruh total penghasilan yang didapatkan baik dalam transaksi online maupun offline. Apabila pengguna ingin melihat laporan pada tanggal tertentu, pengguna dapat memasukkan tanggal awal dan akhir transaksi dengan menekan kotak yang ada di sebelah tanggal awal untuk memasukkan tanggal awal transaksi dan tanggal akhir untuk memasukkan tanggal akhir, kemudian pengguna dapat menekan tombol cari untuk menampilkan laporan penjualan sesuai dengan tanggal yang diinginkan. Pengguna dapat melihat detail transaksi dengan menekan nomor $i d$ pesanan kemudian aplikasi akan menampilkan tampilan detail pesanan yang berisi gambar produk, nama customer, nama produk, jumlah produk yang dibeli pelanggan, alamat pelanggan, tanggal pelanggan memesan produk, jasa kirim, resi pengiriman, dan total harga dari produk yang dibeli. Sebelum masuk ke tampilan laporan penjualan pengguna perlu menekan tombol penjualan pada tampilan home admin.

Tampilan home admin merupakan tampilan pada saat pengguna UD Hoky Celluler Shop berhasil login ke dalam aplikasi menggunakan email yang sudah didaftarkan pada aplikasi. Pengguna dapat melihat stok barang apa saja tersedia pada tampilan home admin dan juga apabila pengguna hanya ingin melihat stok handphone pengguna dapat menekan tombol handphone, apabila pengguna hanya ingin melihat stok aksesoris pengguna dapat menekan tombol aksesoris, apabila pengguna ingin melihat stok barang yang sudah habis, pengguna dapat menekan tombol stock kosong. Pengguna juga dapat melihat detail produk dengan menekan gambar produk kemudian aplikasi akan menampilkan tampilan detail produk. Pengguna dapat memasukkan produk ke dalam keranjang untuk melakukan input transaksi yang terjadi secara offline. Pada tampilan home terdapat juga tombol input produk, list produk, order, penjualan, dan logout. 
Tombol input produk merupakan tombol untuk menampilkan tampilan input produk. Pengguna dapat mengisi data produk seperti gambar produk, nama produk , harga produk, deskripsi produk, jumlah produk, dan kategori produk. Tombol list produk merupakan tombol untuk kembali ke halaman utama pada tampilan home admin. Tombol order merupakan tombol untuk menampilkan tampilan order yang berisi pesanan dari pelanggan. Pada tampilan order pengguna dapat melihat pesanan dari pelanggan, status pesanan, melakukan verifikasi pembayaran, melakukan input ongkos kirim, melakukan input resi pengiriman dan juga membuka keranjang belanja dengan menekan tombol keranjang. Pada keranjang belanja pengguna dapat melihat produk yang sudah dimasukkan ke dalam keranjang belanja yang dipesan oleh pelanggan yang datang ke tempat. Pengguna dapat menghapus produk, menambah jumlah produk, dan mengurangi jumlah produk. Apabila transaksi sudah selesai pengguna dapat menekan tombol selesai pada tampilan keranjang belanja dan transaksi tersebut akan langsung tersimpan ke dalam laporan. Tombol penjualan merupakan tombol untuk menampilkan tampilan laporan penjualan yang berisi semua transaksi baik yang terjadi online maupun offline atau di tempat. Pengguna dapat keluar dari aplikasi dengan menekan tombol logout kemudian aplikasi akan menampilkan tampilan login kembali.

\section{Kesimpulan}

Berdasarkan hasil dari perancangan yang sudah dibuat dapat disimpulkan bahwa aplikasi e-commerce pada UD Hoky Celluler Shop dapat mengatasi masalah dan juga memenuhi kebutuhan yang dibutuhkan oleh UD Hoky Celluler Shop. Aplikasi e-commerce memperluas bisnis UD Hoky Celluler Shop dan memungkinkan untuk mendapatkan pelanggan baru karena dengan menggunakan aplikasi e-commerce, UD Hoky Celluler Shop dapat menjual produknya secara online. Aplikasi ecommerce juga memudahkan UD Hoky Celluler Shop melihat stok produk serta laporan setiap transaksi yang terjadi dicatat secara otomatis oleh aplikasi sehingga proses bisnis UD Hoky Celluler Shop dapat menjadi lebih efektif dan efisien serta memuaskan pelanggan yang membeli produk di tempat karena layanan yang diberikan jauh lebih cepat dibandingkan sebelumnya.

\section{Daftar Pustaka}

A. P. Kusuma and K. A. Prasetya, "Perancangan dan Implementasi E-Commerce untuk Penjualan Baju Online Berbasis Android," Antivirus : Jurnal Ilmiah Teknik Informatika, vol. 11, no. 1, pp. 111, 2017.

[2] I. Rivai, “Aplikasi Toko Online (E-Commerce)
Berbasis PHP." Universitas Muhammadiyah Surakarta, Surakarta, 2016.

[3] Z. A. Tyas, "Implementasi E-Commerce untuk Ozone Distro," PS TI FMIPA Universitas Diponegoro, 2011.

[4] Marjito and G. Tesaria, "Aplikasi Penjualan Online Berbasis Android (Studi Kasus: Toko Hoax Merch)," Computech \& Bisnis, vol. 10, no. 1, pp. 40-49, 2016.

[5] A. D. Riyanto and K. Ma'arif, “Aplikasi MCommerce Berbasis Android pada Zona Komputer Banjarnegara," Telematika, vol. 9, no. 1, pp. 67-77, 2016.

[6] W. Gunawan, E. Nuryani, and M. Prasetya, "Perancangan Aplikasi Android Penjualan Barang dan Jasa Berbasis E-Commerce pada Pixels Computer Cilegon Banten," Jurnal Ilmiah Sains dan Teknologi, vol. 2, no. 1, pp. 51-65, 2018.

[7] L. Tommy, C. Kirana, and V. Lindawati, "Recommender System dengan Kombinasi Apriori dan Content-Based Filtering pada Aplikasi Pemesanan Produk," Jurnal Teknoinfo, vol. 13, no. 2, p. 84, 2019.

[8] A. A. Zabar and F. Novianto, "Keamanan Http dan Https Berbasis Web Menggunakan Sistem Operasi Kali Linux," Komputa : Jurnal Ilmiah Komputer dan Informatika, vol. 4, no. 2, pp. 69-74, 2015.

[9] F. R. Lupi and N. Nurdin, "Analisis Strategi Pemasaran dan Penjualan E-Commerce pada Tokopedia.com," Jurnal Elektronik Sistem Informasi dan Komputer, 2016.

[10] M. Ichwan and F. Hakiky, "Pengukuran Kinerja Goodreads Application Programming Interface (API) pada Aplikasi Mobile Android (Studi Kasus Untuk Pencarian Data Buku)," Informatika, vol. 2, no. 2, pp. 13-21, 2011.

[11] Minarni and Susanti, "Sistem Informasi Inventory Obat Pada Rumah Sakit Umum Daerah (RSUD) Padang," Jurnal Momentum, vol. 16, no. 1, pp. 103-111, 2014.

[12] A. Setiyadi and T. Harihayati, "Penerapan SQLite pada Aplikasi Pengaturan Waktu Ujian dan Presentasi," Majalah Ilmiah UNIKOM, vol. 13, no. 2, 2015.

[13] Y. Bassil, "A Simulation Model for the Waterfall Software Development Life Cycle," International Journal of Engineering and Technology, vol. 2, no. 5, pp. 742-749, 2012.

[14] M. Mulyadi, "Penelitian Kuantitatif dan Kualitatif Serta Pemikiran Dasar Menggabungkannya," Jurnal Studi Komunikasi dan Media, vol. 15, no. 1, p. 128, 2013.

[15] I. N. Rachmawati, "Pengumpulan Data dalam Penelitian Kualitatif: Wawancara," Jurnal Keperawatan Indonesia, vol. 11, no. 1, pp. 35-40, 2007. 